Article

\title{
Social Innovation for Sustainability: The Case of Oil Producing Communities in the Niger Delta region
}

\author{
Christian Omobhude *(1) and Shih-Hsin Chen \\ Institute of Management of Technology, National Chiao Tung University, Hsinchu City 30010, Taiwan; \\ lbxshc@nctu.edu.tw \\ * Correspondence: chrisomobhude.mt04g@nctu.edu.tw
}

Received: 14 October 2019; Accepted: 26 November 2019; Published: 28 November 2019

\begin{abstract}
This study demonstrates how social innovation may engender development as well as peace in deep-rooted poverty and conflict regions in the Niger Delta context. By means of a qualitative study involving oil producing communities in the Niger Delta, this study identifies the dynamics, relevant actors and factors that foster social innovation, creating particular socio-economic outcomes, and contributes to the role of institutions in this context. Our findings suggest that active stakeholders' engagement, facilitation and contributions from key actors significantly influences the quality of economic and social outcomes, but not necessarily environmental outcomes. This allows us to advance the theory on social innovation by analyzing the mechanisms through which social intervention processes may alter the lives of ordinary community members in areas where social and economic interventions are seriously required.
\end{abstract}

Keywords: social innovation; institutional analysis and development; sustainability; ownership; peacebuilding; Niger Delta

\section{Introduction}

This study is about "social innovation", understood to shed light on the role of social, economic and environmental assets in advancing dynamic forces of innovation in a particular region [1,2]. Social innovation is a concept germane to portraying processes and mechanisms that communities adopt to respond and adapt to predicaments. With rising instability from factional and ethnic clashes within oil producing communities in the Niger Delta, there has been growing calls to try out alternative methods that have the potential to improve development opportunities, particularly as Nigeria relies on crude oil produced in the Niger Delta region [3]. As a result, stakeholders have advocated for the use of social innovation as a way to lessen poverty, generate employment, promote rural development [4], enhance legitimacy [5,6] and address policy difficulties and market failures [7]. This is largely because of the relationship between innovation, poverty alleviation and bottom-of-the pyramid issues $[4,8,9]$, which is reflected by an increasing number of published papers across multidisciplinary fields [10,11]. Accordingly, policy makers have identified social innovation as a potentially effective approach for tackling community challenges such as those connected to provision of amenities, environment, social and energy challenges.

However, because of the infancy of social innovation in oil producing communities in Nigeria, we know little about the ways that actors influence social innovation, and much less about how and why social innovation is used. Certain gaps exist in current literature on social innovation. There is no consensus in the literature regarding which social needs are addressed through social innovation and who is involved [12]. In addition, ambiguity surrounds the concept of social innovation that warrants clarification, and the use of the term social innovation often reveals semantic difficulties, producing multiple, interchangeable and mixed understandings [13]. For example, social innovation 
has been described as: A maze or a container concept that is vaguely represented [14-18]. While the vagueness of social innovation may have advanced debates regarding the concept, it also significantly confines theoretical understanding on social innovation processes and outcomes. It is less clear whether social innovation practices, aimed to meet social needs in better ways than pre-existing solutions, actually promote or hinder sustainable conditions that strengthen the civil society. Therefore, this study aims to explore the relationship between institutional arrangements and social innovation that drives sustainability. In order to achieve this aim, the following research questions are posed to guide the direction of this study: (1) To what extent does institutional arrangement shape social innovation initiatives in oil producing communities in the Niger Delta region, and (2) does any connection exist between social innovation practices and sustainability in the Niger Delta region? Giving answers to the above question will be helpful in contributing to an understanding of the literature on how social innovation occurs as well as provide insight on key institutional arrangements that influence the practice of social innovation in a sustainable manner, particularly in comparable regions of similar characteristics within the Niger Delta area. This paper is organized as follows. Section 2 describes the theoretical backgrounds for social innovation, sustainability and connections between social innovation and sustainability, as well as the Institutional Analysis and Development framework, which was adapted to the social innovation case. Section 3 provides details on the research methodology used in this study. Section 4 presents the findings of the study organized according to components of the adapted theoretical framework to answer the research question that deepens understanding concerning institutional arrangements and social innovation. Section 5 provides concluding remarks and policy recommendations.

\section{Theoretical Background}

\subsection{Social Innovation}

Social innovation arose to meet the unmet needs resulting from failure of markets, state and civil society's attempts to change and reorganize the prevailing ways of addressing unmet needs of a disadvantaged social segment by mobilizing people through novel social movements that may have sole or manifold bases of institutional support [19]. Gupta, Dey [19] identify three types of failures that necessitate social innovation. First, market failure, which ensues when the cost at which remedy is available is outside the range of accessibility to a majority of the individuals and groups who require the solution. Second, the failure of the state that occurs when policy fails to target the most impacted individuals or adopts indicators which do not consider the benefits of the needy from present systems. Third, civil society failure arising from inability of voluntary organizations, due to inadequate or infeasible resources, to extend benefits to the marginalized social segment. Because of these failures, some of the impacted individuals and groups may create a reachable, inexpensive, adjustable solution accessible to the needy. Therefore, adopting an empathic approach allows different stakeholders to propose views and exchange ideas, which supports delivery of personalized public services in innovative ways through opening and allocating ownership with the public [20]. Social innovation concerns the need to recognize society as important elements for societal development intended to empower underprivileged individuals to take more responsibility and control of their lives [21-25]. Social innovation provides collaborative advantages where different stakeholders and individuals can collectively construct service to achieve sustainability [26,27], which allows valuable learning for participants to articulate experiences as well as identify niche innovations and promote exchange of ideas among different actors [28,29]. Social innovation essentially focuses on systems that support public needs, create social value in the face of failed policies as well as emphasize self-inclusion for provision of expected benefits to society [30,31]. Society benefits from local participation as local knowledge and skills produce tailor-made solutions to existing problems, which provides sustainable benefits and poverty reduction through sharing of physical and social infrastructure [6,32-34]. The effectiveness of social enterprises is contingent on the degree to which individuals and firms endeavor to develop towards 
open innovation that provides productive mechanisms to advance operations [35]. Local participation targets poverty reduction and inequality in society through contribution by end-users, participants, workers and institutions that depend on interrelations and collaborative skills [36,37]. Some resources for social innovation can be limited to urban areas that improve opportunities such as concentration of capital in metropolitan regions rather than in other regions [38,39]. A proper open social innovation strategy needs to maintain a balance between closed, open and social innovation economies, as well as sustain a creative and new combination [40]. Therefore, the context is a crucial component that carries heterogeneous preferences, innovative opportunities and exerts certain institutional influence [41]. The institutions shape the environment for social innovation by providing norms, rules, incentive structure and resources that promote collaboration, legitimization, fairness and accountability [42,43]. Moreover, institutional actors harmonize contending interests and rights of relevant stakeholders such as who should benefit most from intervention initiatives, as well as negotiate expected value, manage relationships and minimize conflicts [44-46]. The external actors or policy brokers from a third party are required to participate through predetermined schemes in order to promote compromise when the different groups cannot agree on a certain proposal [47]. Social innovation actors rely on technology, sustainability performance metrics, sustainability-oriented innovation, paybacks of innovation $[48,49]$, effective leadership competence and cultural adaptation [50,51]. The cultural and social context where social innovation occurs promotes or hinders social innovation, as novelty-centered cultural values promote capabilities that support innovation, while efficiency-focused cultural values do not have significant effects [52]. In addition, context influences strategic flexibility during social innovation for firms to balance conflicting demands of different stakeholders in steering sustainable outcomes that meet criteria for user acceptance [53,54]. Therefore, the effectiveness of openness in innovation is determined by surrounding conditions in regulations, markets and technology [55]. The willingness to take initiative is based on the availability of resources, mentors and ecosystems that support and reinforce innovation, as the ecosystems for social innovation require both community level initiatives, as well as firm contributions alongside policy support [19]. Furthermore, governance attributes significantly influence organizational legitimacy, clarity, dialogue and disclosure arrangements, which improves social innovation performance and minimizes the tendency to disregard collective opinions and compliance with policies [56]. Integrating the voice and opinion of end-users requires leveraging participants' capabilities and foresight to allow effective social change that demands long term planning and design of programs that are socially, ethically and environmentally sustainable [57-59]. While some firms focus on economic aspects for growth and survival, social and environmental elements are mostly intertwined for firms to gather better perception and a positive image of environmental accountability [60-63]. Social innovation requires institutional change, which involves reforming prevailing institutions or occasionally restructuring. However, the ecosystem of social innovation does not develop solely by transformation of current institutions, but through certain situations that require disruption of conventional norms and values in order to realize greater social good [19].

\subsection{Sustainability}

Sustainability refers to the ability to sustain, or a state that can be maintained at a particular level [64]. The United Nations report significantly contributed to the conceptualization of sustainability. In the report published by the Bruntland Commission in 1987, an attempt was made to link the challenges of economic development with environmental issues, as such sustainability was defined as development that satisfies the requirements of the present-day without conceding the capability of upcoming generations to meet their future needs [65]. Since the Brundtland report was published, scholars have progressively pointed out that we can have economic development and sustainability, without a trade-off. In light of this, the concept of sustainability has benefited from scholarly studies. Consequently, the concept of sustainability has been represented using three pillars of sustainability, where each pillar signifies the economy, the environment and society [66,67]. Sustainability is reached under the following conditions: First, when there is economic growth; second, when economic 
growth meets increasing and varying needs of individuals; and, third, when natural resources are preserved in the process of development, as well as recognizing the capacity of the environment to tolerate the pressures that are implications of our everyday activities [68]. Therefore, the best choices are those that meet the needs of society equitably, are environmentally tolerable and economically feasible [69]. Therefore, it can be argued that productive win-win results arise from properly applying the components (pillars) of sustainability as natural resources are conserved, the environment is not threatened, the economy grows and socio-cultural circumstances improve from reverence for human wellbeing [70]. Using an example from tourism, Gurung and Scholz [71] demonstrate that good ecological quality, attractive environments and diversity of plant and animals in a particular habitat can increase tourism revenues, which in turn benefits the individuals from the communities. By this characterization, sustainability entails the concurrent advancement of equitable economic development, environmental protection and social welfare [72].

\subsection{The Relationship Between Social Innovation and Sustainability}

The concepts of social innovation and sustainability are connected, but this relationship has scarcely been identified either by scholarly studies, policy makers or practitioners [73]. The shortage of scholarly studies identifying the link between social innovation and sustainability is partly attributed to the relative newness of social innovation as a field of study. The following illustrates the relationship between social innovation and sustainability. Social innovation is linked to corporate sustainability in terms of creating long term stakeholder value through environmentally friendly means, as well as ecological, social and economic aspects of firms' operations, while simultaneously improving communications by means of complete transparency [74]. The foregoing principle is based on the triple bottom line method (an accounting framework with social, environmental and financial components), where long-term business goals are intertwined with the immediate environment, and thus necessitates social innovation to achieve corporate sustainability. In addition, social innovation has been linked with social sustainability in the sense that social innovation fosters proactive and sustainable governance of a system by developing the needs, resources and institutions of social-ecological systems, as individuals develop and construct socio-ecological problems, generate knowledge to address them, as well as increasingly turn out to be socially involved in tackling such problems [75]. Furthermore, Galdini and Lucciarini [76] provide the link between social innovation and ecological sustainability using a practical example where public administrators extend their municipal public programs to comprise approaches for identifying and integrating needs from growing awareness regarding environmental issues in their region and thus adopting policies, approaches and tools aimed at enhancing usability and accessibility as well as making use of new environmentally friendly materials. The foregoing provides some insight into the relationship between social innovation and elements of sustainability. The solution to vast societal problems is deep understanding of the needs of the involved stakeholders and methods and tools required to meet the unmet needs of the individuals in the community, which contains element of sustainability that balance not only the achievement of business ideas, but also the viability and environmental benefits to humanity [77]. Based on the preceding insight on the relationship between social innovations and sustainability, social innovation can be considered as an approach adopted to attain sustainability either completely (in terms of the three pillars of economic, social and environmental sustainability) or partially by pursing one or more element of the pillars of sustainability.

\subsection{Institutional Analysis and Development (IAD) Framework}

The stages model introduced by Laswell [78] that analyses policy into different stages (starting from agenda setting through implementation and evaluation stages) remains one of the main reference points for public policy studies, partly because it allows researchers and analysts to make comparisons between countries with identical policies [79]. However, because of different policy actors and external influences, the stages model has been difficult to apply to different contexts [80,81]. In addition, 
the value chain approach identifies different activities and phases necessary to actualize products or services until delivery to users and disposal after use [82]. Within the value chain approach, different actors hold particular positions that sequentially linked in the chain of operations such that one activity in a particular value chain or link is successively influenced by the output of upstream activities that must be recognized in a downstream link. However, in reality activities are not sequentially organized as the action situations are complex and iterative. The value chain approach is suited for a functional business perspective that involves a chronological production lifecycle [83].

Understanding the institutional environment of social innovation can be messy stemming from the complex and interconnected sets of factors affecting social innovation processes and outcomes. Other frameworks such as the above-mentioned approaches can illuminate interesting features of social innovation, but we argue that such frameworks may be too narrow and less appropriate for representing the complexities of social innovation. In addition, existing approaches do little to explain institutional influences and behaviors that affects outcomes of social innovation. The Institutional Analysis and Development framework is appropriate for focusing attention on institutional structures of the connections and linkages among different processes of social innovation, as well as consequences of actors' decisions. Therefore, we adopt the Institutional Analysis and Development framework to understand complexities and linkages between different parts and processes of social innovation.

Institutions are systems of established and prevalent social rules, enduring features of social life that structure political, economic and social interactions [84-86]. Some examples of institutions include: Schools, shops, post offices and police forces [87]. Institutional conditions are included into strategic choices, which afford researchers opportunity to examine the ways that individuals maximize benefits under constraint of institutional conditions. The Institutional Analysis and Development framework was first developed by Ostrom to study interactions between individual choice and institutional situation [88], and it analyses individual economic behavior into a number of related and commonly controlled aspects that allow thorough investigation of societal issues [89]. The Institutional Analysis and Development framework has been widely adopted to study the management of collective common resources and it has been used to study both fixed institutional arrangements, as well as dynamic institutional arrangements of rules and innovations [90-92]. To use the Institutional Analysis and Development framework for social innovation management, we need to first identify where individuals interact, exchange goods and services and solve problems [89,93]. The components of the Institutional Analysis and Development framework that can be used to examine how features of governance systems might lead to certain outcomes, which suggests that individual rational choices are determined by exogenous and endogenous factors. The exogenous factors include aspects of socio-cultural, institutional, and physical environments where participants are embedded. The endogenous factors include actors, action situations and activities of individuals that influence the decision-making of actors and affect structures of behavior. The endogenous factors determine how individuals interact with exogenous factors. Together, outcomes are influenced by both exogenous and endogenous variables initiated by assessment of actions and outcomes according to observed processes [94].

\subsection{IAD Framework Adapted to Social Innovation}

As Ostrom [95] noted, frameworks shape diagnostic and prescriptive analyses that provide organizing devices to identify components that establish a system, but frameworks do not illustrate how diverse components of the system interact. As an adaptable analytical tool for studying different social phenomena, the IAD framework can be used to systematically analyze relevant variables and components common to different social situations and illustrate factors likely to affect policy outcomes in a particular situation $[94,96,97]$. The core unit of analysis in the IAD framework is the action arena, which characterizes actors, action situations, strategies and interactions to unify and direct resources toward particular outcomes [98]. By following the steps in the IADF framework, and using the action arena as the unit of analysis, this study systematically examines the institutional arrangement that affects social innovation. While we take the action arena as the main unit of analysis, it is also 
important to identify circumstances that lead to their formation $[99,100]$. According to important exogenous conditions identified in the literature on social innovation, we modified and adapted the IAD framework (Figure 1) to identify the institutional arrangements and structural relationship in context.

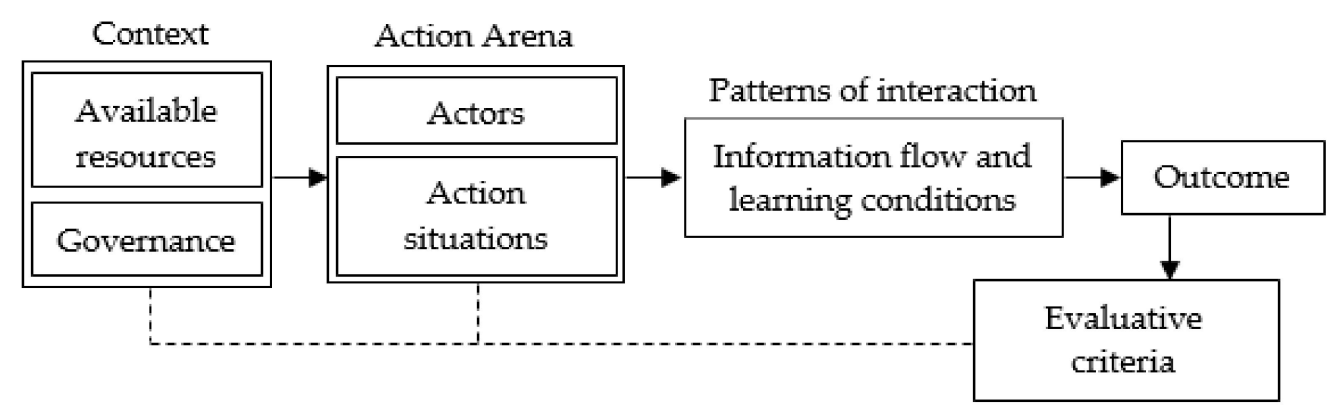

Figure 1. Modified institutional analysis and development (IAD) framework for social innovation.

The modified IAD framework inherits the essential structure of the initial IAD framework, except that the contextual category has been modified to include the political and economic contexts of the system that resonates with the biophysical conditions. In this sense, the added component of governance and resource reflects the periodization analysis that shows how institutions remain on a particular trajectory until continual path(s) can no longer attain intended goals [101]. The exogenous variables within the context category have been renamed but follow generally from the original concept. Availability of resources is germane in terms of promoting social innovation, and the resources are crucial in environmental concerns and in managing various forms of biophysical attributes [102-106]. Governance includes the structural elements of government and active external organizations pertinent to policy development [107-111]. Additionally, feedback following evaluation provides information that influence decisions within the action arena and informs governance attributes, which in turn promotes innovation activities and enhances activity [112,113]. Other components (action arena, patterns of interaction, outcomes and evaluative criteria) of the IAD framework remain unchanged.

Table 1 provides a brief summary of key concepts taken from the IAD framework and applied to structure analysis of the social innovation case.

Table 1. A brief summary of key concepts and their definitions.

\begin{tabular}{|c|c|c|}
\hline \multicolumn{2}{|c|}{$\begin{array}{l}\text { Key Concepts from the Theoretical } \\
\text { Background }\end{array}$} & Description of the Concept \\
\hline \multirow[t]{2}{*}{ Context } & Available resources & $\begin{array}{l}\text { Supply of material and assets that can be drawn on by } \\
\text { stakeholders in order for social innovation to function. }\end{array}$ \\
\hline & Governance & Actions, rules, control and ways of governing. \\
\hline \multirow[t]{2}{*}{ Action Arena } & Actors & $\begin{array}{l}\text { Individuals or groups who portray a character in social } \\
\text { innovation and undertake social actions. }\end{array}$ \\
\hline & Action situations & $\begin{array}{l}\text { Social space where individuals and groups interact and solve } \\
\text { problems. }\end{array}$ \\
\hline Interactions & Patterns of interaction & Existing possibilities in which actors interact with one another. \\
\hline \multirow[t]{2}{*}{ Outcomes } & Outcomes & $\begin{array}{l}\text { Results that follow as a consequence of pattern of interactions by } \\
\text { actors in the action arena. }\end{array}$ \\
\hline & Evaluation criteria & Standards against which outcomes are measured. \\
\hline
\end{tabular}

The above conceptual framework (Figure 1), using the concepts described in Table 1, was applied to understand the institutional arrangements that influence social innovation in oil producing regions of the Niger Delta. The conceptual framework was used to organize a collection of relevant information concerning the biophysical context, which comprises resources and governance structures prevalent 
in the communities; the action arena where social innovation actors undertake certain actions and interact to solve societal problems; patterns of interactions that exist amongst actors; outcomes that arise from social innovation activities; as well as evaluation criteria applied against observed outcomes. The components of the conceptual framework were operationalized as correlates with specific aspects of the framework. For example, respondents were asked questions concerning the local biophysical conditions, community attributes and institutional rules-in-use that affect the implementation of social innovation practices and outcomes in their communities, as well as questions about the key actors and actions associated with social innovation. Following data collections and compilation, the relevant information was iteratively analyzed based on elements of the conceptual framework. By following the steps in the conceptual framework, the analysis systematically follows the path of social innovation from inception to post-implementation (monitoring and evaluation).

\section{Methodology}

This study examines institutional arrangements that shape social innovation. Our research design is based on recommendations by Yin [114] that qualitative methodology is helpful for in-depth empirical investigation on real-life phenomenon within context, especially when margins between the phenomenon and context are not evident. Qualitative methodology is more suitable for exploring experiences, perspectives and views of relevant participants, which are not amenable to quantitative approaches [115-117]. The remainder of this section explains how data was collected and consequently analyzed.

\subsection{Data Collection}

Data collection lasted from June 2018-October 2018 and was driven by purposive and snowballing sampling techniques [118]. The different qualitative research methods used to enhance reliability and strengthen corroboration of result in this study include semi-structured interviews (59 participants), documentary analysis, focus group discussions and observation in order to discover existing institutional arrangements, mechanisms and processes of social innovation. Hereafter, we elucidate with regards to details of the research methods used in this study.

\subsubsection{Semi-Structured Interviews}

A pilot study was first conducted to evaluate the effectiveness of interview questions and used to refine the interview protocol. Participants for the pilot study comprised two individuals from the oil sector (firm and regulatory agency) and two individuals from oil-producing communities, selected for their experiences and potential to contribute adequately to shaping and revising the interview questions. 59 semi-structured interviews were conducted, averaging around $1 \mathrm{~h}$ each, with consent for recording provided by participants. There were four main segments that characterized participants' affiliation, namely oil firms, regulatory (government) agency, community representatives and intermediating organizations. Participants were required to answer open-ended questions, follow up questions, as well as additional questions necessitated by other interview discussions, which were all related to the research question. The interview protocol was linked to the research questions, based on the components of the IAD framework. Table 2 below summarizes the category of questions developed, as well as descriptions aimed to get to the core of the underlying category. 
Table 2. Category and information sought from the interview protocol.

\begin{tabular}{|c|c|}
\hline Category of Questions & Questions Were Asked to Understand: \\
\hline Resource systems & $\begin{array}{c}\text { How the dominant oil sector has promoted social innovation } \\
\text { The importance of resource characteristics (size, economic value, distribution } \\
\text { and interaction among resource elements) } \\
\text { Built facilities and efficiency of systems }\end{array}$ \\
\hline Governance systems & $\begin{array}{c}\text { The predominant organizations, namely government and nongovernment } \\
\text { organizations, structure of networks } \\
\text { Prevailing property rights, as well as monitoring and sanctioning rules }\end{array}$ \\
\hline Actors & $\begin{array}{c}\text { The demographic nature and characteristics of actors as well as intensity of } \\
\text { involvement } \\
\text { The function(s) of different groups of actors } \\
\text { Existing norms and available capital } \\
\text { Facilitation techniques and processes to promote social innovation } \\
\text { Perceptions on challenges associated with tools and processes } \\
\text { The extent of receptiveness from other actors and institutions }\end{array}$ \\
\hline $\begin{array}{l}\text { Action situations: } \\
\text { Interactions and } \\
\text { outcomes }\end{array}$ & $\begin{array}{c}\text { Communication, dialogue and information sharing approaches } \\
\text { Conflicts and conflict resolution approaches } \\
\text { Networking, interventions and self-organizing activities } \\
\text { Monitoring and evaluative activities such as performance measures on } \\
\text { sustainability, ownership and accountability } \\
\text { The status quo in terms of finance, programs and outreach } \\
\text { Citizens' representativeness and equality considerations } \\
\text { Expectations contrasted with actualized outcomes } \\
\text { Description of effectiveness from perspective of each group of actors }\end{array}$ \\
\hline
\end{tabular}

In terms of selection criteria, participants were selected through purposive and snowballing sampling largely because of their positions, knowledge and experiences regarding the topics that were investigated. Confidentiality was important to ensure answers provided were honest. Therefore, we provided guarantees of anonymity to participants, and presented the findings without using real names in order to maintain privacy.

\subsubsection{Focus Group Discussion}

This study involved 12 focus group discussions covering ordinary community members and sub-groups of elders, traders, farmers, disabled, youths, women, council of chiefs and religious leaders. Each focus group comprised between 7 and 10 participants who share similar characteristics as advocates for change. We, the researchers, acted as moderators of the focus group discussion between participants, and we were present to ask questions, facilitate discussions and take notes. Initial conversation with participants and documentary analysis shaped the list of questions that steered the discussion while also permitting flexibility to modify sequence of topics discussed depending on how conversations developed. Information acquired from focus group discussions was triangulated with other sources of data for sufficient representation from different perspectives in order to improve reliability and discover the meaning of the data.

\subsubsection{Secondary Literature}

Documentary evidence, solicited from firms and individuals before interview sessions, provided valuable data that explained institutional practices and processes of social innovation. These documents included official records, reports, contracts, request for proposals and minutes of meetings that were interpreted to provide meaning around the topic being assessed. Some documents provided by participants were comprehensive, whereas others did not cover every aspect related to the topic. As a result, documentary evidence, used alongside other sources of data collection, highlighted additional 
questions that needed to be explored during semi-structured interviews as well as situations for observation, which ensured data collected was comprehensive and critical.

\subsubsection{Observation}

Observation was used to collect data in the natural setting where participatory activities and events occur within communities. We, as researchers, played the role of bystanders in order to allow a more objective approach where participants were less aware that they were being observer, in order to avoid false behavior that may not represent the natural setting. It is recommended for the observer to be detached as not to be noticed by participants to reduce the Hawthorne Effect where participants are aware of being studied, and possible impact on behavior [119]. The relevant stakeholders were informed about observation activity in order to grant access to participation sessions where we collected notes concerning comments, actions, activities and locations. Particular aspects that participants were unable to share during semi-structured interviews or through documentary sources were directly observed. Furthermore, we were able to check for verbal and nonverbal expressions such as emotions, patterns of interactions, duration of meetings and participatory sessions. Observation led to new follow-up questions further explored through semi-structured interviews, as well as encouraged request for additional documents from relevant participants.

\subsection{Analysis}

The process of data analysis converged with the phase of data collection. Transcription of data collected influenced follow-up questions, as well as requested documentary evidence and observation. The data collected from different sources was analyzed for main themes following key elements of the analytical framework. Preliminary versions of transcripts were provided to respondents to verify accuracy of information when required and feedback was collected to develop the final versions of transcripts. For analysis, particular consideration and priority was given to in vivo codes that place emphasis on the actual words of the participants, in order to represent themes that resonate with respondents. In addition, descriptive and process codes were also used to represent patterns, actions and topics from collected data. An attempt was made to capture the essence of the content with clarity to portray meaning that participants intended. As a matter of thoroughness, we, the researchers, collectively reviewed the results for consensus prior to reporting the findings.

\subsection{Research Site}

The Niger Delta region (comprising nine oil producing states: Abia, Akwa-lbom, Bayelsa, Cross-River, Delta, Edo, Imo, Ondo and Rivers) has been selected to understand institutional arrangements and influences on social innovation. The Niger Delta is strategic to the socio-economic development of Nigeria because of wealth of crude oil in the region. As an oil-reliant country, crude oil derived from the Niger Delta is the main exportable product, as well as the foremost source of revenue and earnings for Nigeria. Oil production and the associated instability in the Niger Delta have caused health issues and poverty for local residents who survive on fishing and farming. Oil spills and weak industry practices have taken a substantial toll in the Niger Delta area [120]. As a result, the Niger Delta is rife with conflicts arising from perceived injustice and quests for resource control. The insecurity in the Niger Delta region as a conflict prone area is different from other regions where government, through military intervention, is able to curb chaos and crisis. All efforts to resolve conflicts in the region have failed, including the amnesty program of 2009 that was declared by the Nigerian government, which temporarily allowed militants to surrender their arms and ammunitions [121]. The region has subsequently deteriorated into chaos with renewed militancy disrupting oil production activities and unsettling peace in the region. Efforts by authorities to resolve conflicts in the Niger Delta have been far from successful because they have not sufficiently addressed issues that produced conflict and emphasis on the use of military force. The strategic importance of the Niger Delta region, in terms of its contribution to the country's earnings through crude oil exploration and exports has 
attracted widespread attention. In recent years, there are groups of actors and negotiators increasingly involved in deploying alternative means for resolving conflicts in the Niger Delta region, through social innovation that applies bottom-up participation in order to find lasting peace and in turn develop oil producing communities. These parties believe that social innovation provides alternatives for cooperation, which is necessary for resolving and avoiding the recurrence of imminent conflicts in the Niger Delta region. Given the infancy of social innovation in the Niger Delta, this study allows us to understand the roles of actors and how they facilitate social innovation processes within particular institutional arrangements.

\section{Findings}

The research question guiding this study is: To what extent does institutional arrangement shape social innovation initiatives in the oil producing communities in the Niger Delta region. The findings presented in this section illustrate institutional arrangements and influences on social innovation across oil-producing communities in the Niger Delta region.

\subsection{Context}

\subsubsection{Available Resources}

The agitation for resource control in the Niger Delta started in the 1990s under the Movement for the Survival of the Ogoni People (MOSOP), as the people of the Niger Delta region hold the view that the community was the default owner of resources (crude oil and gas) that accrued from their land, and the federal government was expected to share the oil proceeds with oil producing communities. The divergent interest intensified calls for resource control which resulted in bitterness and other forms of ethnic and political clashes. The issue of resource control in the Niger Delta has since remained a highly combative political and economic issue that continues to threaten the stability of the region. This was because activities associated with oil exploration and exploitation in the region often adversely affect the biodiversity, as well as the communities who depend on this biodiversity for survival. As some individuals in the communities held the view that oil resources belong to the community, they therefore expressed dissatisfaction with being ignored in decision-making on what they assumed to be communal resources.

"In the past, oil companies and authority did not maintain good relationship with host communities. The companies came to our land for oil exploration and production but did not consult with communities, thereby keeping people out of important decisions such as environmental impact assessment studies and necessary decisions" (interview, Community Representative 5).

The consequence of excluding the communities from decision-making has been undesirable, causing rising social unrest including demonstrations and protest.

"The public order disturbance has significantly increased in the past 10 years, from protest to killings and kidnappings of both local and foreign oil workers. The recent unrests have been broader in scope and greater in frequency than a decade ago. Fears of rising unrest has triggered a national debate regarding strategies to implement reforms and appropriate way to respond to violence in oil producing communities" (interview, Government Official 2).

\subsubsection{Governance}

The findings suggest that the first attempt to tackle community disturbance, which affected oil revenue proceeds, was militarization of the Niger Delta. The government instituted military structures to govern and suppress community agitations. The poor governance structure has led to poor economic development and many deaths in the region and it is manifested through political instability, ineffective rule of law and dissolved institutions. The presence of military in the Niger Delta did not go far in achieving the aims of combating violence and stemming killings and vandalism perpetuated by a 
Niger Delta militant group referred to as 'The Niger Delta Avengers (NDA)'. The governance structure of the time produced certain outcomes that intensified resentment.

"There were unintended and dangerous consequences by militarization of the Niger Delta. Innocent civilians in the Niger Delta paid a high price with many killed and widespread destruction of homes and property because of the battle that pitted the military against the Niger Delta Avengers" (interview, NGO Representative 4).

The lingering conflicts continued to weaken oil activity in the region until it was realized that the use of force was not an appropriate governance strategy to tackle the crisis in the Niger Delta region. Therefore, to quell violence and insurgency, the federal government implemented an unconditional amnesty program that allowed militants who were demanding resource control, environmental justice and sustainable socio-economic development to drop their arms and weapons. These actions ensured that governance was enhanced, and were viewed as a good starting point to building a relationship between communities and authority.

“... disarmament, demobilization, and reintegration (DDR) strategy which focused on collecting arms, reintegrating ex-combatants into military or civilian life, and avoiding reoccurrence to armed struggle. The DDR program has been implemented and has achieved some level of victory in reducing armed conflicts and sustaining peace in the Niger Delta region" (interview, Government Official 1).

A temporary ceasefire was reached with militant groups, many arms and weapons were recovered and destroyed, but before long other militant factions and groups emerged. The issue of poor governance and malpractice was blamed for the failure of sustained peace in the Niger Delta region because the policies were designed to pacify aggrieved militants rather than identify and solve impending issues that originally caused militant surge. As a result, while one group of militants (Movement for the Emancipation of the Niger Delta (MEND)) were granted presidential amnesty and reintegrated into the society, by sponsoring them in vocational and higher education courses, other militant factions (such as the Niger Delta Avengers and Niger Delta Greenland Justice Mandate) emerged and continued sustained attacks on oil producing facilities in the Niger Delta regions, which lead to the shutdown of significant oil terminals and decrease of oil production to the lowest level in more than two decades which adversely affected the Nigerian economy and budget. Some blamed the governance system for being too narrow in terms of considering only the needs of the armed militia groups, which suddenly pushed the communities back into clashes and ethnic struggles triggered by dissatisfaction that stirred up renewed violence centered around arguments that government was not addressing the widespread needs of the community.

"I felt disappointed by the boys that surrendered as the interest of the Niger Delta was exchanged for money. The amnesty program did not address the fundamental issue of resource control but instead urged us to return our weapons for selfish gains when our lands were still being polluted by oil contamination, our resources was taken away without reciprocation and the army imposed curfew on movement in our community" (interview, Community Representative 3).

The top-down governance strategy used for decision-making imposed decisions and expectations on communities that were far from what was necessary for the creation of a peaceful community where oil companies could operate undisturbed. The pre-existing governance system failed to address looming challenges which further incentivized other groups to intensify demands for self-determination. It was soon realized that the failures associated with declining crude oil revenue result from the flawed governance and systemic failure of institutional arrangements underpinned by paradigmatic assumption like 'divide and rule', which appeals to the dominant group, with unintended consequences that strengthened continued escalation of violence and conflict by other less dominant groups in the Niger Delta region. As a result, the government introduced a different governance strategy that provided adequate parameters to carry along every stakeholder, starting with legislative provisions and establishing institutions to attend to issues of the Niger Delta people. One respondent indicated that this was a significant step forward. 
"Without this deliberate and established space for local integration, there was no way we could achieve peace in the region. Therefore, we provided opportunities to engage indigenous businesses in oil and gas activities, which were previously exclusive to foreign multinationals, through introduction of the Nigerian Oil and Gas Industry Content Development Act 2010" (interview, Government Official 5).

The majority of interviewees believe that the legislation (Oil and Gas Industry Content Development Act) was beneficial to improving local capacity in the oil and gas industry, which was previously dominated by an expatriate workforce that affected domestic labor creation. The legislation provides that Nigerian operators shall be given first consideration in virtually every field of oil activity such as award of oil blocks, oil field licenses, oil lifting licenses, employment and training and contracts. Learning from the success of the legislation, which was critical to local ownership of oil related resources by indigenous companies, communities proposed a similar approach be used for resource management in their individual communities, in order to improve their ability to collectively manage and overcome resource challenges. The community demanded a governance approach that ensures new developments appreciate the views of the stakeholders and surrounding context and takes an integrated approach that brings together expertise, resources and dialogue between stakeholders from within the community.

"The collective governance system led to the formulation of the Niger Delta regional development master plan that was conceived as a tool to actualize desires of the Niger Delta people. The plan provided every stakeholder in the community with opportunity to actively participate in decision-making process through dialogue and negotiation as a basis for development of the Niger Delta region. At the center of the development plan is the contribution of stakeholders which determines the state of affairs in the Niger Delta region" (interview, Government official 3).

This set the stage for community participation at all stages of the decision-making process, which were coordinated by different actors responsible for decisions at any given stage. We found that stakeholders were actively involved and responsibility of corresponding stakeholders helped determine proper approaches for policy formulation in the region. Through newly adopted bottom-up strategy, communities were able to communicate their goals and develop to-do lists that they perceived were necessary for development, which led to the proliferation of both state and non-state actors that elevated the involvement status and influence of the community.

\subsection{Action Arenas: Actors and Action Situations}

The findings in this section is organized around the actors (individuals and groups), and how they are routinely involved in the action situations through interaction to solve problems. The main actors include: Government agencies, community members, facilitators and oil and gas companies.

\subsubsection{Government Agencies}

The federal government agency responsible for development of the Niger Delta region is predominantly the Niger Delta Development Commission (NDDC), Department of Petroleum Resources (DPR) and the Ministry of Niger Delta. These government departments coordinate efforts to tackle challenges of infrastructure development, environment protection and youth empowerment in the Niger Delta region. In addition, there are other state controlled government establishments such as the Ministry for Local Government Affairs that work collectively with federal government agencies. Government (regulatory) authority confirmed that provisions were made for active community participation in the Niger Delta. This was corroborated through fieldwork observation and documentary evidence. The authorities encouraged participation in development planning initiatives at different administrative levels based on dialogue and consensus with communities, resource capacity and reliable information for participatory endeavors. For this reason, oil and gas companies report to regulatory agencies on budgeted fiscal amounts reserved for development activities, which require the approval of allocations and plans by the authority. In addition, conflicts were initially reported to government agencies for alternative dispute resolution according to signed agreements before escalation to any court of law. It 
was widely agreed by respondents that government optimized the role of the state in reducing the adverse consequences of crises and creating appropriate conditions aimed at improving the quality of dialogue in communities.

"Stakeholders productivity centers around how effective we do our job in ensuring communities are not destroyed at the expense of resource extraction. Doing this correctly and with active community involvement helps reduce tensions and obtain clear understanding of expectations of community and performance standards required" (interview, Government Official 7).

\subsubsection{Community Members}

The community is represented by individuals from different groups across communities, including: The elders, youths, women, disabled, traders, farmers, council of chiefs and religious leaders. These members, whose representatives constitute the Community Development Committee (CDC), are appointed by communities and endorsed by traditional leaders based on customs and traditions. Because not all community members can be represented on the board of the community development committee, appointed representatives have the power to convey requests and expectations of the body of people within the individual groups. Collectively, community representatives engage in discussions and influence final decisions for community development. Among community members, the findings showed that youths have more power than other community members.

The incidence of youth restiveness was linked to the negative side of social development associated with the prevalence of high illiteracy, poverty and structural unemployment in the communities, which degenerated into a topical issue (mass protests, vandalism, cultism, ethnic militia, inter (intra)-ethnic conflicts and violence) that result in loss of lives and properties.

"Youths draw our attention because of their association with issues such as violence and vulnerability to different forms of crisis as many of them are unemployed. More often than not, when their concerns are not addressed, situations could easily spiral out of control causing violence that costs millions in damages and often loss of lives which we do not want" (interview, Firm Representative 4).

The challenges of youth employment were given additional attention in communities that have been affected by violence, in order to keep youths out of the streets. The findings suggest that it was important for stakeholder and authority to take proactive steps to ensure that community youths do not get out of control. The reality on the ground demonstrates that many of these youths do not immediately engage in violent behavior until they perceive they are being ignored. Therefore, proactive measures taken by stakeholders were to listen to the youths, engage in dialogue when required, to understand their values, opinions and emotions, and sympathize with their concerns. Essentially, the goal was to look at issues from the point of view of the youth, and support lasting solutions for social challenges. Some respondents believe that behaviors of youths are triggered by systemic risk events externalized from frustrations.

“... rising unemployment among youths was one of the main reasons for their involvement in militant activities. Therefore, we provide vocational and education training that is focused on fields such as oil and gas, maritime services, construction, transportation, and agriculture. We absorb a few qualified youths directly into our workforces, provide recommendations for others and we also have scholarship programs available for prospective applicants who wish to continue formal education. It is expected that youth empowerment would allow beneficiaries find work in private sector or start up a business" (interview, NGO Representative 1).

The integration of community interest and improved participation has strengthened the bargaining and leadership position of the community. A prominent example is reflected by the practice of right of first refusal. The community actively participates in leading, managing and implementing social innovation programs, as exemplified by the last look provision, which gives community individuals the opportunity and priority to express interests as contractors and the right to negotiate before the authority puts the offer on the open market. In this sense, the community holds the right of first refusal, 
and if the community declines any contract bid, then the oil and gas companies can subsequently enlist support from whomever they desire.

"We have contractual agreements with all stakeholders that provides the right to community in matters such as contract awards, employment and as recipients of services based on specified terms, before oil companies are allowed to enter into any transactions with individuals from outside the community" (interview, Community Representative 6).

The communities being traditionally agricultural and poor, it is only recently that education started to receive widespread attention, as many individuals remain illiterate, which means that not much can be expected of them in terms of utilizing the foremost role and opportunity provided to community. However, to preserve the peace, measures were taken to ensure that, despite these weaknesses, communities do not perceive they are being shortchanged. The solution was to recruit consulting bodies, adopt services of non-government organizations, as well as utilize expertise from within the oil and gas companies (such as the project management team) to facilitate financial and technical supervision of contracts awarded to community contractors.

In addition to the formal practices for community participation that included the policies and procedures in place that allowed active community involvement, the findings showed there were also practices that were less than formal, and which were needed to curb the potential excesses by power brokers in the community to prevent them from exploiting the process and using it for their own advantage. The traditional leaders in communities benefited personally as they were given stipends, gifts for birthdays, funeral sponsorships and paid-for (full package) weekends in the cities. Such practices are generally allowed according to the customs and traditions of the community, which pays homage to traditional ruling councils as they have a greater ability to influence development plans than other community members, but it sometimes produced grievances and envy among community youths.

\subsubsection{Facilitators}

The non-government organizations and experts with concentration on oil and gas and poverty alleviation provide a different facilitation perspective on social innovation activities. The facilitators support individuals and groups from the community to identify priorities and assist to design and plan ways that objectives can be achieved. Many of these facilitators remain neutral but they often take particular positions with the community during discussions. These facilitators supervise participatory activities and ensure stakeholders are monitored and accountable for actions and outcomes avoid misunderstanding. Some of the present practices are shaped by history.

"Previous experience shows that leaving oil companies to their own devices, some of them would reach an agreement with communities without providing necessary tools that ensure proper planning and implementation. It is important to remember the main task of oil companies is not to facilitate community engagement, which is only a byproduct of their regular operations" (interview, NGO Representative 2).

The main task of facilitators is preparing communities through preplanning and planning activities that identify problems and prioritize how participatory activities are conducted. This approach is followed by generating agreement across communities, with involvement of government agency and oil company representatives through consensus building. A related role of facilitators is that many community members have too limited skills, knowledge and experience to take up participatory work of development planning and implementation in communities. The facilitators are expected to manage activities and resolve conflicts among stakeholders within communities.

Many facilitators also perform advocacy roles by taking long-term views as activists for or against certain cause(s). For example, we found that in addition to the facilitation role played by enablers (such as NGOs and expert researchers), there is consistent advocacy for complete removal of certain practices, escalation of issues to international bodies and advocacy for resettlement and compensation to be paid to victims of unfair practices. The advocates specify that they intend to help communities that are 
threatened by destructive impacts of development to take control of their lives. The vulnerability of individuals in communities is worsened by environmental factors.

"The issue of oil spill is different in Nigeria, as companies disregard their spills and destroy livelihood and environments such as the famous Ogoniland oil spill. We criticize some oil companies over inattentiveness to plights of oil producing communities in the Niger Delta. Especially in Bayelsa where oil companies have majority of their operations, the consequences of their activities impact adversely on lives of the people" (interview, NGO Representative 5).

Furthermore, it was found that facilitators also engaged in consultations with international bodies involved in humanitarian and environmental issues, in order to promote awareness for rehabilitation of the Niger Delta through collective actions.

\subsubsection{Oil and Gas Companies}

Oil and gas companies provide required financial resources for sponsorship of social innovation projects. The amounts budgeted are projected against expected revenue, and consequently deposited in joint accounts managed by all community stakeholders. These stakeholders equally determine the nature of projects to be implemented, based on adequacy of funds provided, and usefulness of projects which are collectively determined by all stakeholders involved. While decision to allocate specific amount for social innovation and intervention projects fall within parameters of participatory guidelines stipulated by government agencies, many oil and gas companies have adopted a practice to allocate at least three percent of their annual revenue towards social innovation. The international oil and gas companies allocate a lot more towards social intervention projects in different fields. The activities of the oil and gas companies are strategically oriented towards reassigning resources to more beneficial projects and programs. One leading oil and gas company representative suggest that:

"Our actions are strategically motivated to specialized aspects in development processes that provides improvement in welfare of the community. The community is lacking in many areas; therefore, we provide certain infrastructure that we believe can bring about significant improvements in lives of community members. We provide wide range of services such as electricity which is especially important for farmers to preserve perishable crops like tomatoes, and we also provide social infrastructure such as maternity wards, hospitals, health centers water and mostly investment in education for increased prospects for employment and other forms of socio-economic upliftment" (interview, Firm Representative 1).

Within oil and gas companies, participatory activities are coordinated by corporate affairs division executives, which include the corporate affairs managers and community liaison officers. These practitioners are often recruited from within the community, and must be able to speak the same language of the communities where they operate. Prior unfavorable incidents led oil companies to strategically select appropriate representatives in terms of skill and communication ability in order to provide satisfactory services to a community.

"Our experience shows that communities find it hard to trust people from outside their community, especially for communities that have experienced some environmental issues. Therefore, it is particularly necessary to build trust and confidence as a crucial first step in communicating with communities in their dialect. When they know that the company representative comes from their community, then they often believe that he or she also wants the best outcomes for the community" (interview, Firm Representative 3).

Our observation confirmed that the background of the company representative plays a big role in determining the level of closeness with community leaders. We found that in some communities with foreign company representative, a majority of youths and elders continually agitated for a change, either because of communication difficulty or cultural incompatibility. For this reason, many oil and gas companies recruit people that can be trusted by communities and that are familiar with the culture of host and impacted communities, to build credibility. As is typical and customary for many 
communities, some respondents indicated that having indigenous representatives from the oil and gas company is expected to be beneficial.

"When meetings get out of control and violence erupts, the community cannot kidnap or harm their own indigene. However, this is often not the case with foreign representatives that can be threatened especially in volatile communities in the Niger Delta" (interview, Firm Representative 6).

Another reason why oil producing communities undertake such efforts is because communities appreciate when they or their representatives can freely walk into companies to make complaints and discuss community issues, impromptu, with company representatives. Company representative who are indigenes of the community have little to no option to decline community admittance because they live and reside in the same communities and are considered to be representing the same cause. Therefore, the oil and gas companies perform two fundamental roles, providing finances for social innovation programs and assigning the right person to liaise with the community.

"In many instances, success of community participation depends on company representatives, whether they are willing to listen to us or not. Sometimes, when it gets too difficult to convey our message, we insist that we want to speak directly with the company's CEO" (interview, Community Representative 2).

\subsection{Pattern of Interaction}

Continual community support is only likely when actors are permitted to express their concerns, see their interests considered in participatory projects, and when they anticipate in what way the outcome serves them. An analysis of planning and implementation process provides insight into patterns of interaction for social innovation activities which includes information flow, structures and participatory mechanisms used. Individual actor performs different roles, but they are equally capable of influencing decisions regarding what is required for social innovation activities. The collective interaction was characteristic of social innovation process, which was viewed as crucial by stakeholders for successful implementation. The following identifies different stages where interactions takes place between actors.

\subsubsection{The Planning Phases}

The findings show that interactions rely on learning, exchange of information and feedback. Several learning activities were incorporated in participatory events using town hall meetings, discussions and workshops. The underlying purpose of these activities was to provide opportunity for interactions and learning where communities can identify pressing needs through facilitation techniques such as participatory rural appraisal.

"We guide community members using town hall meeting to identify and streamline several competing projects related to community development. Interaction was prompted by assigned list of projects that have been determined through consultation with community and individual investigation. These activities permitted community members further dialogue in developing community development plans, while we moderate discussions" (interview, Scientific Expert 2).

The different actors provided information and assistance to wider community members in navigate circulated materials relating to proposed community development agenda. Two strategies were overwhelmingly used for interaction among actors, namely communication and feedback.

"We initiate communication in weekly meetings and townhalls by posing questions through dialogue. Additional information and resources are provided to inform participants of the agenda of oil companies and recommended solutions. Feedback that includes facilitator's response to community members and weekly summaries of contents highlighting community contributions are provided" (interview, NGO Representative 6).

Starting from initial meetings, community members shared ideas and reflections relating to development strategies presented in meetings. In response, facilitators and other actors provided clarification of contributions and elaboration beyond initial contributions. This involved relating 
relevant experience and expanding ideas based on available resources. While the contents of planning processes may be different across communities, we found that there is a common collaborative planning process that uses contributions from different sources within communities. The planning process begins with community members working with a single objective to take ownership of development initiatives such that dialogue and discussion in planning leads to translation of community ideas and contributions to the formulation of a memorandum of understanding (MoU). Our findings and observations demonstrated that the MoU document is one of the most important aspects of social innovation and social intervention programs. The document provides pragmatic guidance on how community development takes place, identifies intervention projects and carries corresponding approval by relevant actors and authorities. Across different stages of social innovation initiative, the $\mathrm{MoU}$ directs program planning and implementation, identifies potential constraints, schedule of staffing, resources and budgeting, as well as stakeholders' engagement procedures.

"The memorandum of understanding provides a framework for when and how to conduct collaborations with actors. It speaks of the mechanism and timing to consider certain projects in the community, and given the reality that many communities feel overwhelmed with several needs, and complexity of realizing their expectations for development through support from oil companies and stakeholders, the MoU begins by responding to the question, 'what should be done and how?' (interview, Firm Representative 5).

Our findings showed that the MoU guide is renewed periodically, mostly between three and five years, to reflect realities in communities; the guide is signed and approved by every stakeholder and it responds to a series of questions that need to be addressed to have a responsive social innovation process in any community in the Niger Delta. In addition, the MoU spells out the principles for conflict resolution and appointed representatives who are eligible to interface as stakeholders.

\subsubsection{The Implementation Phases}

The planning process produces a strategic implementation plan that defines implementation strategy in communities. The implementation strategy outlines the roles and responsibilities, resources, budget and expected outcomes for intervention initiatives. Unlike the planning phase, which identifies pressing needs and points out the course of action, the implementation of social intervention programs was performed differently.

"The implementation method tailor-made to social innovation is a prerequisite for successful implementation. This comprises controlling and monitoring necessary activities, and provides a roadmap for realizing a return on investment on services delivered for many years to come" (interview, Government official 4).

The post-planning stage linked with implementation requires dialogue and negotiation where each actor reaches an agreement on planning documents submitted by oil and gas companies for subsequent application. To increase the transparency of the social innovation process, all planning decisions are declared on public domains such as newspapers, company websites and local radio stations, requesting that interested participants get involved and tender bids.

"For the implementation of physical projects such as hospital, schools, borehole and road construction, we provide structured invitation to indigenous contractors and suppliers from host communities to submit a bid to implement intervention projects. Other benefits such as scholarship opportunity, training and skill acquisition are announced using regular media outlets and traditional town crier for people to participate and enroll in such programs" (interview, Firm Representative 2).

One significant finding is that the implementation of programs is carried out exclusively by community members, with the supervision of external stakeholders. There is strict adherence to the principle of first refusal that prioritizes community involvement throughout every phase of participatory initiative. Financial disbursement to community contractors and suppliers is collectively approved by every stakeholder based on assessments and reports provided for the quality of work 
completed. Therefore, even though the community is actively involved, they are supervised and held accountable to predetermined standards.

\subsection{Outcomes and Evaluation Criteria}

Our findings demonstrate that one of the most important outcomes of social innovation is the sense of ownership that it provides. It was widely agreed by respondents that social programs were largely owned by the people who planned and created the initiatives.

"Individuals in the community get the feeling that what is provided is theirs, with higher sense of ownership towards projects. We have experienced that individuals with strong sense of ownership are more committed to the process of participation and therefore consider it their responsibility for protecting projects from being vandalized" (interview, Government Official 6).

In addition, the issue of sustainability was a recurring theme that featured throughout participants' responses.

"Above anything else, sustainability ensures that projects and benefits realized are maintained and continue after the end of the project's external funding from oil companies. The intervention projects maintain flow of benefits for a long period after the project inputs have ceased, and community must be capable on their own without assistance of outside development partners, to continue to produce results for their benefits" (interview, Firm Representative 9).

The following excerpt highlights a typical example of how the issue of sustainability of social intervention is addressed in the community, a common approach widely recounted by participants across all the communities.

"When we provide canoes, ferry, drinking water projects and town halls, we encourage communities to commercialize these projects in order to generate revenue stream independently through rental fee and other income that is in turn used to manage and maintain projects in the long term. Such implementation and sustainability blueprint are designed collectively within planning agreements" (interview, NGO Representative 3).

For government and oil and gas companies, social innovation ensures adequate provision of, and accessibility to, basic services and infrastructure by vulnerable members of communities, and more importantly peacebuilding for the oil firms to operate for stable fiscal oil revenues.

"Social innovation through participatory process was central to ensuring sustainable peace which respects the rights and presence of oil and gas companies, as well as allows community individuals freely pursue their wellbeing and development. However, equally important is that we need peace to be able to extract oil and gas, particularly in conflict-prone and fragile communities in Niger Delta" (interview, Government Official 8).

Our findings and observations confirmed that the delivery of intervention outcomes was not the end of the process of social innovation. The facilitators, as part of the MoU requirements, continually evaluated projects and empowerment initiatives by collecting and analyzing information on social programs, features and outcomes in order to determine judgements about the sustainability of intervention activities.

"It is important to periodically evaluate and adjust activities to confirm they are as effective as intended. This helps to identify areas for improvement which can eventually support set-out goals. We go back to the drawing board, and provide reports about what outcomes were more or less effective and sustainable, which helps improve decision-making for subsequent programs" (interview, NGO Representative 7).

To the extent that particular evaluations have specific purposes, different criteria were used to conduct evaluations across communities, based on their meaningfulness, expenses and trade-offs. There were standard evaluation criteria used for social innovation across all communities in the Niger Delta that included resource utilization, actualized outcomes and socio-economic sustainability.

"We evaluate the extent that intervention projects are consistent with community needs and policies of the authority. There is assessment of how efficiently resources are transformed to results, 
and the extent that development interventions were achieved. The primary and secondary long-term effects produced by projects and initiatives, intended or unintended, as well as continuation of benefits after projects have been completed are equally evaluated" (interview, NGO Representative 9).

The evaluation process allows actors to demonstrate the success or the failure of intervention projects by using information to feedback and communicate how projects impact communities. We found that this was important for public relations for oil and gas companies, government agencies and other actors, in terms of attracting and retaining support for social innovation programs.

\subsection{Summary of Findings}

The result contributes to the growing field of inquiry into social innovation from the perspective of the Niger Delta. Our findings regarding the extent that institutional arrangements shape social innovation initiatives in the oil producing communities in the Niger Delta region can be summarized as follows. Institutional arrangements are a significant part of social innovation in the oil producing communities. The existing institutional arrangements comprise partnerships of stakeholders including individuals, oil firms, interest groups and regulatory agencies that interact and coordinate needs assessments and negotiation activities and implement agreements for socio-economic upliftment in oil producing communities. The institutional arrangements are structured to provide a system of separation of powers that ensures that a particular individual or group will have select control over particular domains of responsibility for facilitating social innovation, thus preventing any specific entity from concentration or abuse of powers. In this sense, institutional arrangements are shaped by exchanges among stakeholders, political regimes and social and cultural norms in the community to provide a sense of belonging and improve the wellbeing of the community, as well as facilitate the peacebuilding required for oil and gas companies to operate smoothly. Furthermore, an important finding is that the existing institutional arrangements only focus on the social and economic dimensions of sustainability. The issue of environmental sustainability was not included on the agenda for social innovation in oil producing communities of the Niger Delta region.

\section{Conclusions and Policy Recommendations}

The research questions guiding this study are: (1) To what extent does institutional arrangement shape social innovation initiatives in the oil producing communities in the Niger Delta region? and (2) does any connection exist between social innovation practices and sustainability in the Niger Delta region? This understanding is absent in the extant literature on social innovation. Accordingly, this study adds to the emerging debate on the intricacies (institutional actors, processes and mechanisms) of social innovation, from the perspective of the Niger Delta region. The empirical finding shows that institutional arrangements significantly influence social innovation, as actors, interrelationships and rules support multilateral exchanges used to collectively find a consensus that is subsequently implemented for socio-economic transformation. In agreement with Yun and Liu [122], our findings agree that firms adopt open platforms to produce and maintain innovation ecosystems, and the role of government has evolved from regulation towards facilitation, as societies and end users are starting to develop novel concepts which leads to a shared economy. The findings show that social innovation is not only beneficial to the community in terms of providing social services but also to firms enabling environments of peace that allow the firms to operate undisturbed. This is aligned with the findings from Yun, Won [55] who argued that open strategies that aim to improve cost advantage and compatibility with other practices are more effective, and the success of social enterprises depends on how they attempt to move towards open innovation, as implementing open innovation strategies is productive in developing operational outcomes. The findings from this study are consistent with Montagnino [123] and show that the evolving paradigm of sustainability provides a challenging field comprising with evolving practices, regulations and business models that affects decision making which has paved the way for inclusive and responsible innovation strategies that provide changes towards ethical development. Community participation without appropriate institutional arrangements does 
not possess richness in terms of the resource pools such as expertise, intermediation, policies and negotiation that institutional arrangements necessitate to improve the quality of socio-economic outcomes. Some corporations endeavor to reach people at the bottom of the pyramid through flexible interchanges between firms and communities that can be followed through with mechanisms with or without the intermediation of a third party [19]. Based on evidence from this study, we found that the success of social innovation in the Niger Delta region is thus contingent on effective institutional strategies, involving the intermediation of third parties, which plays an important role in strengthening policies and translating urgent needs of communities into sustainable outcomes. The opportunities for social innovation are embedded within collaborative institutions. Different stakeholders, such as firms, NGOs, government agencies and community members, among others, contribute towards sustainable outcomes. It is agreeable, as with the findings by Yun, Won [124], that the role of firms and government investments are vital in supporting continual and creative social innovation beyond an ordinary level, which induces collaboration and contributions using various channels such as financial systems and policy. The firms provide the financial support necessitated by policy formulation and compliance supervision provided by government. Consistent with Lee and Jung [47], the different views and strategies of various stakeholders may be contradictory in calling for intercession by a third group of actors whose main role is to identify practical conditions in order to lessen struggles with an unbiased position. As a result, community members can articulate their needs through either violent or non-violent means which may aggravate the situation to insurgency if policy persists [19]. From the findings, social innovation has significantly reduced the need for violent escalations that persistent prior to practices of social innovation. Essentially, the success of social innovation is largely based on the institutional arrangement that supports what Gupta, Dey [19] identify as the five As, namely: Affordability, accessibility, acceptability, adaptability and availability of the solution.

The practices of social innovation in the Niger Delta region are linked with two pillars of sustainability: The social and economic aspects of sustainability (Figure 2).

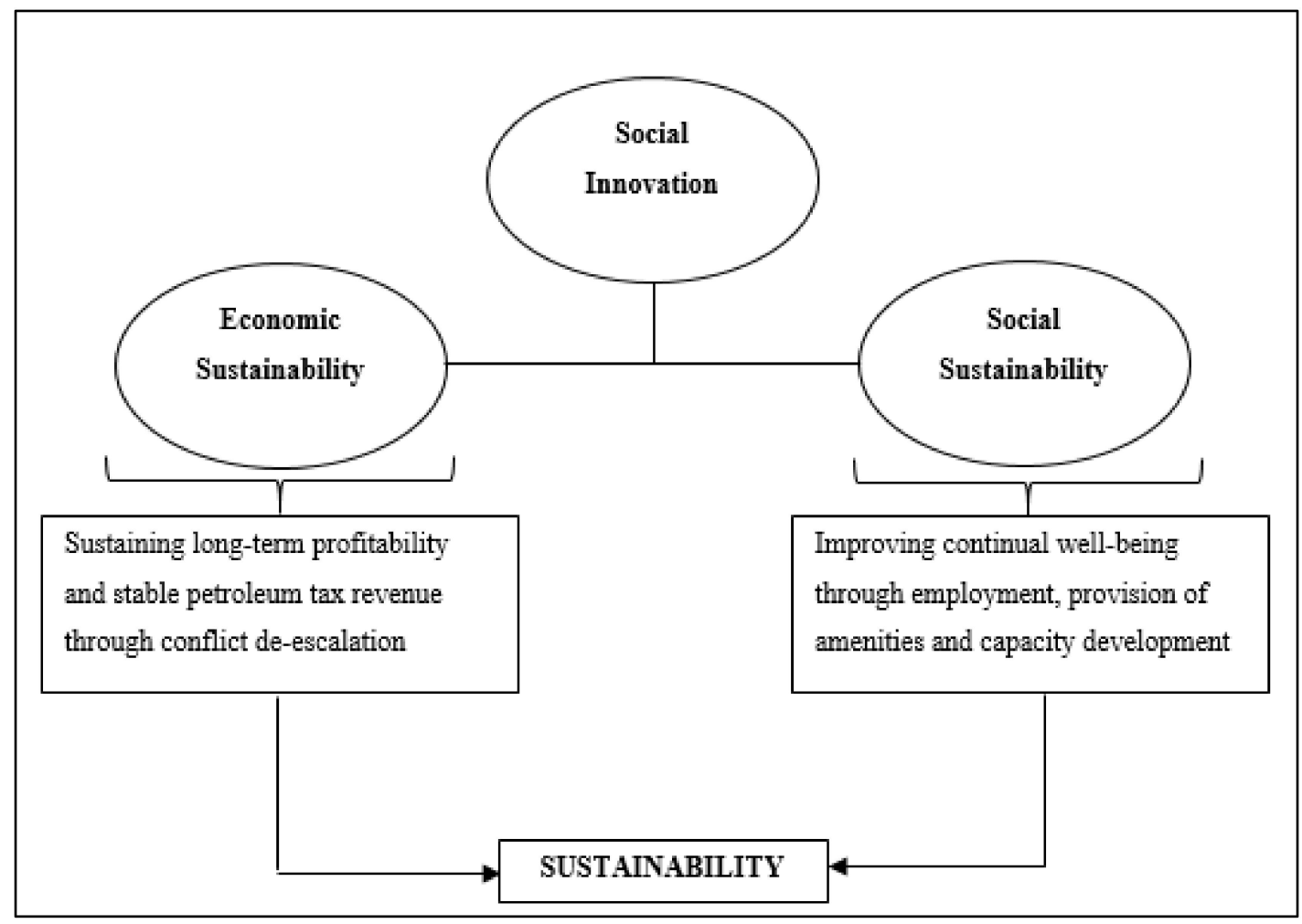

Figure 2. Connection between social innovation and sustainability (Author's elaboration). 
In terms of the economic pillar of sustainability, the oil firms and the government pursue social innovation to promote effective utilization of resources to their best advantage in order to reduce clashes and conflict in the communities, which in turn provide long-term benefits (stable oil revenue) and profitability for oil companies. A profitable oil firm in the Niger Delta is more likely than an unprofitable one to remain stable and continue to provide revenue, from one year to the next, to the Nigerian government which heavily depends on crude-oil revenue. Regarding the social pillar of sustainability, social innovation attempt to balance the needs of the individual and groups of the community through the provision of services and infrastructure that improves long-term social wellbeing. Some of these social intervention initiatives include a refocus on employment of locals; amenities and infrastructure development; training; provision of scholarship opportunities; and capacity empowerment. Surprisingly, there was no connection between social innovation practices and the environmental pillar of sustainability, as there is currently no strategy put in place to include discussions concerning environmental problems emanating from gas flaring, oil spills and contamination produced by activities of oil exploration and exploitation. It appears that the environmental aspect of sustainability is left to a future consideration which is currently missing from the agenda of social innovation. The economic and social aspects of sustainability are interrelated. The more profits that accrue to the oil firms from peaceful and receptive communities, the more the oil firms are able to allocate, financially, towards social programs that improve the wellbeing of the community. In turn, the more the community is satisfied with the oil firms from the provision of service that meet their unmet needs, the more hospitality the oil firms will receive for peaceful operations.

The findings from this study provide certain implications for policy makers and practitioners concerned with social innovation. The implications of social innovation are consistent with the legacy of Beuys, described in Montagnino [123] as changing our daily action and, collective determination toward a new emergent stage of humanity that is based on a holistic vision of society that promotes the interconnection of individuals to produce constructive change in protection of nature and against the isolation of humanity in order to generate circumstances that allows individuals the capacity, the willingness and the ability to envisage alternatives and desirable futures. Implementing an emphatic strategy of service design allows policymakers to recognize the perspectives of other stakeholders, instead of keeping to their own views, which may be limited [20]. Therefore, there is a need to move from a short to a long-term (sustainable) perspective that explores the creative and entrepreneurial potential for substantial cooperative progress in the direction of an innovative evolutionary phase of civilization through an all-inclusive understanding of society, economy and nature. The environmental aspect of sustainability cannot be relegated because of the health and social implications of this neglect. Indeed, as Yun, Park [125] found, our findings imply that we have to consider new roles of government in promoting innovation dynamics from a systemic perspective through the construction of permissionless innovations and stimulating a sharing economy using incentive systems. Policy might be needed to mandate holistic refocus on environmental sustainability, but whether or not the firms are able to afford and implement technology for environmental sustainability targets is a question beyond this study.

Nevertheless, it is important that relevant actors collaborate with community members and external stakeholders so as to generate funding for social innovation and formulate novel intervention programs that reduce deprivation and promotes development. This study sheds light on the importance of collaborative decision-making for the provision of public services and how it might help promote sustainable social outcomes and peace for companies to operate in communities. The findings from this study advance the scope of knowledge to apparent new kinds of actors, relations and structures within participatory mechanisms. Notwithstanding, Nigeria's developed oil and gas industry and the exploration for oil and gas in other non-Niger Delta communities are still growing as well as developments in non-oil sectors. Viewed from this perspective, this study also carries deep meaning to practitioners in Nigeria's developing sectors and communities, as social innovation may provide options to exercise resources and abilities in non-conventional ways. As a closing remark, in light of 
the peculiarity of the Niger Delta region, the findings of this study must be cautiously applied to other comparable contexts that have similar community attributes as well as institutional actors that support and finance social innovation activities.

Author Contributions: Conceptualization, S.-H.C. and C.O.; Research Design, S.-H.C. and C.O.; Methodology, S.-H.C. and C.O.; Literature review: S.-H.C. and C.O.; Data curation, C.O.; Preliminary Data analysis, C.O.; Investigation, C.O.; Supervision, S.-H.C.; Visualization, C.O.; Writing- Preliminary draft, C.O.; Writing-Review \& editing, S.-H.C. and C.O.

Funding: This research was funded by Ministry of Science and Technology, MOST [106-2410-H-001-009-MY2] and Ministry of Education [PBM1080392].

Conflicts of Interest: The authors declare that there is no conflict of interest.

\section{References}

1. Moulaert, F; Nussbaumer, J. The Social Region: Beyond the Territorial Dynamics of the Learning Economy. Eur. Urban Reg. Stud. 2005, 12, 45-64. [CrossRef]

2. Geobey, S.; Westley, F.R.; Weber, O. Enabling Social Innovation through Developmental Social Finance. J. Soc. Entrep. 2012, 3, 151-165. [CrossRef]

3. Watts, M. Petro-Insurgency or Criminal Syndicate? Conflict Violence in the Niger Delta. Rev. Afr. Political Econ. 2007, 34, 637-660. [CrossRef]

4. George, G.; McGahan, A.M.; Prabhu, J. Innovation for Inclusive Growth: Towards a Theoretical Framework and a Research Agenda. J. Manag. Stud. 2012, 49, 661-683. [CrossRef]

5. Halme, M.; Lindeman, S.; Linna, P. Innovation for Inclusive Business: Intrapreneurial Bricolage in Multinational Corporations. J. Manag. Stud. 2012, 49, 743-784. [CrossRef]

6. Hall, J.; Matos, S.; Sheehan, L.; Silvestre, B. Entrepreneurship and Innovation at the Base of the Pyramid: A Recipe for Inclusive Growth or Social Exclusion? J. Manag. Stud. 2012, 49, 785-812. [CrossRef]

7. Grimm, R.; Fox, C.; Baines, S.; Albertson, K. Social innovation, an answer to contemporary societal challenges? Locating the concept in theory and practice. Innovation 2013, 26, 436-455. [CrossRef]

8. Chataway, J.; Hanlin, R.; Kaplinsky, R. Inclusive innovation: An architecture for policy development. Innov. Dev. 2014, 4, 33-54. [CrossRef]

9. Pansera, M.; Owen, R. Framing inclusive innovation within the discourse of development: Insights from case studies in India. Res. Policy 2018, 47, 23-34. [CrossRef]

10. Edwards-Schachter, M.; Wallace, M.L. 'Shaken, but not stirred': Sixty years of defining social innovation. Technol. Forecast. Soc. Chang. 2017, 119, 64-79. [CrossRef]

11. Van der Have, R.P.; Rubalcaba, L. Social innovation research: An emerging area of innovation studies? Res. Policy 2016, 45, 1923-1935. [CrossRef]

12. Lundström, A.; Zhou, C. Promoting innovation based on social sciences and technologies: The prospect of a social innovation park. Eur. J. Soc. Sci. Res. 2011, 24, 133-149. [CrossRef]

13. Dias, J.; Partidário, M. Mind the Gap: The Potential Transformative Capacity of Social Innovation. Sustainability 2019, 11, 4465. [CrossRef]

14. Pellicer-Sifres, V.; Belda-Miquel, S.; López-Fogués, A.; Aristizábal, A.B. Grassroots Social Innovation for Human Development: An Analysis of Alternative Food Networks in the City of Valencia (Spain). J. Hum. Dev. Capab. 2017, 18, 258-274. [CrossRef]

15. Graddy-Reed, A.; Feldman, M.P. Stepping up: An empirical analysis of the role of social innovation in response to an economic recession. Camb. J. Reg. Econ. Soc. 2015, 8, 293-312. [CrossRef]

16. Edwards-Schachter, M.E.; Matti, C.E.; Alcántara, E. Fostering Quality of Life through Social Innovation: A Living Lab Methodology Study Case. Rev. Policy Res. 2012, 29, 672-692. [CrossRef]

17. De Muro, P.; Hamdouch, A.; Cameron, S.; Moulaert, F. Organisations de la société civile, innovation sociale et gouvernance de la lutte contre la pauvreté dans le Tiers-Monde. Mondes Dev. 2007, 139, 25-42. [CrossRef]

18. Mulgan, G.; Tucker, S.; Ali, R.; Sanders, B. Social Innovation: What It is, Why It Matters and How It Can be Accelerated; Basingstoke Press: London, UK, 2007.

19. Gupta, A.; Dey, A.; Singh, G. Connecting corporations and communities: Towards a theory of social inclusive open innovation. J. Open Innov. 2017, 3, 17. [CrossRef] 
20. Kim, T. Identifying Stakeholders and Interactions in the Dementia Café in Seongju through Empathic Service Design Approaches. J. Open Innov. 2018, 4, 28. [CrossRef]

21. Mulgan, G. The Process of Social Innovation. Innovations 2006, 1, 145-162. [CrossRef]

22. Cajaiba-Santana, G. Social innovation: Moving the field forward. A conceptual framework. Technol. Forecast. Soc. Chang. 2014, 82, 42-51. [CrossRef]

23. Neumeier, S. Why do Social Innovations in Rural Development Matter and Should They be Considered More Seriously in Rural Development Research?-Proposal for a Stronger Focus on Social Innovations in Rural Development Research. Sociol. Rural. 2012, 52, 48-69. [CrossRef]

24. Teece, D.J. Business Models, Business Strategy and Innovation. Long Range Plan. 2010, 43, 172-194. [CrossRef]

25. Pol, E.; Ville, S. Social innovation: Buzz word or enduring term? J. Socio Econ. 2009, 38, 878-885. [CrossRef]

26. Li, L.; Kung, H.C.; Tsai, F.S.; Liu, C.F.; Lu, K.H. Service Learning, Service Climate, and Service-Based Social Innovation for Sustainability. Sustainability 2018, 10, 2566. [CrossRef]

27. Piccarozzi, M. Does Social Innovation Contribute to Sustainability? The Case of Italian Innovative Start-Ups. Sustainability 2017, 9, 2376. [CrossRef]

28. Peters, B.; Herens, M.; Brouwers, J. Capturing Social Innovations in Agricultural Transformation from the Field: Outcomes of a Write-Shop. Sustainability 2018, 10, 4727. [CrossRef]

29. Polese, F.; Botti, A.; Grimaldi, M.; Monda, A.; Vesci, M. Social Innovation in Smart Tourism Ecosystems: How Technology and Institutions Shape Sustainable Value Co-Creation. Sustainability 2018, 10, 140. [CrossRef]

30. Bock, A.J.; Opsahl, T.; George, G.; Gann, D.M. The Effects of Culture and Structure on Strategic Flexibility during Business Model Innovation. J. Manag. Stud. 2012, 49, 279-305. [CrossRef]

31. Silva, E.G.; Teixeira, A.A.C. Does structure influence growth? A panel data econometric assessment of "relatively less developed" countries, 1979-2003. Ind. Corp. Chang. 2011, 20, 457-510. [CrossRef]

32. Thomas, H.; Fressoli, M.; Becerra, L. Science and technology policy and social ex/inclusion: Analysing opportunities and constraints in Brazil and Argentina. Sci. Public Policy 2012, 39, 579-591. [CrossRef]

33. Bird, F. The Practice of Mining and Inclusive Wealth Development in Developing Countries. J. Bus. Ethics 2016, 135, 631-643. [CrossRef]

34. Khavul, S.; Bruton, G.D. Harnessing Innovation for Change: Sustainability and Poverty in Developing Countries. J. Manag. Stud. 2013, 50, 285-306. [CrossRef]

35. Yun, J.J.; Park, K.; Im, C.; Shin, C.; Zhao, X. Dynamics of Social Enterprises-Shift from Social Innovation to Open Innovation. Sci. Technol. Soc. 2017, 22, 425-439. [CrossRef]

36. Zhong, X.; Ozdemir, S.Z. Structure, learning, and the speed of innovating: A two-phase model of collective innovation using agent based modeling. Ind. Corp. Chang. 2010, 19, 1459-1492. [CrossRef]

37. Demircioglu, M.A.; Audretsch, D.B.; Slaper, T.F. Sources of innovation and innovation type: Firm-level evidence from the United States. Ind. Corp. Chang. 2019, 28, 1365-1379. [CrossRef]

38. Stam, E.; Thurik, R.; van der Zwan, P. Entrepreneurial exit in real and imagined markets. Ind. Corp. Chang. 2010, 19, 1109-1139. [CrossRef]

39. Bradley, S.W.; McMullen, J.S.; Artz, K.; Simiyu, E.M. Capital Is Not Enough: Innovation in Developing Economies. J. Manag. Stud. 2012, 49, 684-717. [CrossRef]

40. Yun, J.J. How do we conquer the growth limits of capitalism? Schumpeterian Dynamics of Open Innovation. J. Open Innov. 2015, 1, 17. [CrossRef]

41. Cano-Kollmann, M.; Hamilton, R.D.; Mudambi, R. Public support for innovation and the openness of firms' innovation activities. Ind. Corp. Chang. 2016, 26, 421-442. [CrossRef]

42. Arora, S.; Romijn, H.A.; Caniëls, M.C.J. Governed by history: Institutional analysis of a contested biofuel innovation system in Tanzania. Ind. Corp. Chang. 2013, 23, 573-607. [CrossRef]

43. Lashitew, A.A.; Bals, L.; van Tulder, R. Inclusive Business at the Base of the Pyramid: The Role of Embeddedness for Enabling Social Innovations. J. Bus. Ethics 2018, 1-28. [CrossRef]

44. Crucke, S.; Knockaert, M. When Stakeholder Representation Leads to Faultlines. A Study of Board Service Performance in Social Enterprises. J. Manag. Stud. 2016, 53, 768-793. [CrossRef]

45. Bosse, D.A.; Coughlan, R. Stakeholder Relationship Bonds. J. Manag. Stud. 2016, 53, 1197-1222. [CrossRef]

46. Rühli, E.; Sachs, S.; Schmitt, R.; Schneider, T. Innovation in Multistakeholder Settings: The Case of a Wicked Issue in Health Care. J. Bus. Ethics 2017, 143, 289-305. [CrossRef]

47. Lee, K.; Jung, K. Exploring institutional reform of Korean civil service pension: Advocacy coalition framework, policy knowledge and social innovation. J. Open Innov. 2018, 4, 14. [CrossRef] 
48. Kennedy, S.; Whiteman, G.; van den Ende, J. Radical Innovation for Sustainability: The Power of Strategy and Open Innovation. Long Range Plan. 2017, 50, 712-725. [CrossRef]

49. Kotabe, M.; Dunlap-Hinkler, E.; Parente, R.; Mishra, H.A. Determinants of cross-national knowledge transfer and its effect on firm innovation. J. Int. Bus. Stud. 2007, 38, 259-282. [CrossRef]

50. Mithani, M.A. Innovation and CSR_Do They Go Well Together? Long Range Plan. 2017, 50, 699-711. [CrossRef]

51. Warner, K.S.R.; Wäger, M. Building dynamic capabilities for digital transformation: An ongoing process of strategic renewal. Long Range Plan. 2019, 52, 326-349. [CrossRef]

52. Sánchez-Báez, E.A.; Fernández-Serrano, J.; Romero, I. Organizational culture and innovation in small businesses in Paraguay. Reg. Sci. Policy Pract. 2019. [CrossRef]

53. Perry, P.; Wood, S.; Fernie, J. Corporate Social Responsibility in Garment Sourcing Networks: Factory Management Perspectives on Ethical Trade in Sri Lanka. J. Bus. Ethics 2015, 130, 737-752. [CrossRef]

54. Candi, M.; Melia, M.; Colurcio, M. Two Birds with One Stone: The Quest for Addressing Both Business Goals and Social Needs with Innovation. J. Bus. Ethics 2018, 1-15. [CrossRef]

55. Yun, J.J.; Won, D.; Park, K. Dynamics from open innovation to evolutionary change. J. Open Innov. $2016,2,7$. [CrossRef]

56. Riivari, E.; Lämsä, A. Organizational Ethical Virtues of Innovativeness. J. Bus. Ethics 2019, 155, $223-240$. [CrossRef]

57. Youssef, B.A.; Boubaker, S.; Omri, A. Entrepreneurship and sustainability: The need for innovative and institutional solutions. Technol. Forecast. Soc. Chang. 2018, 129, 232-241. [CrossRef]

58. Grewatsch, S.; Kleindienst, I. How organizational cognitive frames affect organizational capabilities: The context of corporate sustainability. Long Range Plan. 2018, 51, 607-624. [CrossRef]

59. Kolk, A. The social responsibility of international business: From ethics and the environment to CSR and sustainable development. J. World Bus. 2016, 51, 23-34. [CrossRef]

60. Christmann, P.; Taylor, G. Globalization and the Environment: Determinants of Firm Self-Regulation in China. J. Int. Bus. Stud. 2001, 32, 439-458. [CrossRef]

61. Regnér, P.; Edman, J. MNE institutional advantage: How subunits shape, transpose and evade host country institutions. J. Int. Bus. Stud. 2014, 45, 275-302. [CrossRef]

62. Eiadat, Y.; Kelly, A.; Roche, F.; Eyadat, H. Green and competitive? An empirical test of the mediating role of environmental innovation strategy. J. World Bus. 2008, 43, 131-145. [CrossRef]

63. Gupta, S.; Kumar, V. Sustainability as corporate culture of a brand for superior performance. J. World Bus. 2013, 48, 311-320. [CrossRef]

64. Kajikawa, Y. Research core and framework of sustainability science. Sustain. Sci. 2008, 3, 215-239. [CrossRef]

65. UN. Report of the World Commission on Environment and Development: Our Common Future; United Nations General Assembly. Development and International Co-operation; Environment: New York, NY, USA, 1987.

66. Schoolman, E.D.; Guest, J.S.; Bush, K.F.; Bell, A.R. How interdisciplinary is sustainability research? Analyzing the structure of an emerging scientific field. Sustain. Sci. 2012, 7, 67-80. [CrossRef]

67. Kastenhofer, K.; Rammel, C. Obstacles to and potentials of the societal implementation of sustainable development: A comparative analysis of two case studies. Sustainability 2005, 1, 5-13. [CrossRef]

68. Hay, J.; Mimura, N. Supporting climate change vulnerability and adaptation assessments in the Asia-Pacific region: An example of sustainability science. Sustain. Sci. 2006, 1, 23-35. [CrossRef]

69. Porter, M.E.; van der Linde, C. Toward a New Conception of the Environment-Competitiveness Relationship. J. Econ. Perspect. 1995, 9, 97-118. [CrossRef]

70. Kaivo-oja, J.; Panula-Ontto, J.; Vehmas, J.; Luukkanen, J. Relationships of the dimensions of sustainability as measured by the sustainable society index framework. Int. J. Sustain. Dev. World Ecol. 2014, 21, 39-45. [CrossRef]

71. Gurung, D.B.; Scholz, R.W. Community-based ecotourism in Bhutan: Expert evaluation of stakeholder-based scenarios. Int. J. Sustain. Dev. World Ecol. 2008, 15, 397-411. [CrossRef]

72. Koehler, D.A.; Hecht, A.D. Sustainability, well being, and environmental protection: Perspectives and recommendations from an Environmental Protection Agency forum. Sustainability 2006, 2, 22-28. [CrossRef]

73. Mehmood, A.; Parra, C. Social Innovation in an unsustainable world. In The International Handbook on Social Innovation: Collective Action. Social Learning and Transdisciplinary Research; Moulaert, F., Ed.; Edward Elgar: Cheltenham, UK, 2013. 
74. Osburg, T. Social Innovation to Drive Corporate Sustainability, in Social Innovation: Solutions for a Sustainable Future; Springer: Berlin/Heidelberg, Germany, 2013; pp. 13-22.

75. Parra, C. Social Sustainability, a Competitive Concept for Social Innovation? In The International Handbook on Social Innovation: Collective Action, Social Learning Transdisciplinary Research; Moulaert, F., Ed.; Edward Elgar: Cheltenham, UK, 2013.

76. Galdini, R.; Lucciarini, S. Social Innovation and Environmental Sustainability in Social Housing Policies: Learning from Two Experimental Case Studies in Italy; IntechOpen: London, UK, 2019.

77. Mota, R.; Oliveira, J.F.G. Combining innovation and sustainability: An educational paradigm for human development on earth. Braz. J. Sci. Technol. 2014, 1, 2. [CrossRef]

78. Laswell, H.D. The Decision Process, Bureau of Governmental Research; University of Maryland: College Park, MI, USA, 1956.

79. Anderson, J.E. Cases in Public Policy-Making, 2nd ed.; Holt, Rinehart and Winston: New York, NY, USA, 1982.

80. Sabatier, P.A. The Theories of the Policy Process, 2nd ed.; Westview Press: Boulder, CO, USA, 2007.

81. Sabatier, P.; Jenkins-Smith, H. Policy Change and Learning: An Advocacy Coalition Approach; Westview: Boulder, CO, USA, 1993.

82. Kogut, B. Designing global strategies: Comparative and competitive value added chains. Sloan Manag. Rev. $1985,26,15-28$.

83. Raikes, P.; Jensen, M.F.; Ponte, S. Global commodity chain analysis and the French filière approach: Comparison and critique. Econ. Soc. 2000, 29, 390-417. [CrossRef]

84. North, D. The New Institutional Economics and Development; Washington University: St Louis, MI, USA, 1993.

85. Hodgson, G.M. What Are Institutions? J. Econ. Issues 2006, 40, 1-25. [CrossRef]

86. Giddens, A. New Rules of Sociological Method; Hutchinson: London, UK, 1976.

87. Harre, R. Social Being; Wiley-Blackwell: Oxford, UK, 1979.

88. Kiser, L.; Ostrom, E. The Three Worlds of Action: A Metatheoretical Synthesis of Institutional Approaches. In Strategies of Political Enquiry; Ostrom, E., Ed.; Sage: Beverly Hills, CA, USA, 1982.

89. Ostrom, E.; Gardner, R.; Walker, J. Rules, Games, and Common-Pool Resources; Agrawal, A., Bloomquist, W., Schlager, E., Tang, S.Y., Eds.; The University of Michigan Press: Ann Arbor, MI, USA, 1994.

90. Clement, F.; Amezaga, J.M. Conceptualising context in institutional reforms of land and natural resource management: The case of Vietnam. Int. J. Commons 2013, 7, 140-163. [CrossRef]

91. Benson, D.; Jordan, A.; Cook, H.; Smith, L. Collaborative environmental governance: Are watershed partnerships swimming or are they sinking? Land Use Policy 2013, 30, 748-757. [CrossRef]

92. Polski, M.M.; Ostrom, E. An Institutional Framework for Policy Analysis and Design. In Workshop in Political Theory and Policy Analysis; Indiana University: Bloomington, IN, USA, 1999.

93. Ostrom, E. Crossing the great divide: Coproduction, synergy, and development. World Dev. 1996, 24, 1073-1087. [CrossRef]

94. Ostrom, E. Background on the Institutional Analysis and Development Framework. Policy Stud. J. 2011, 39, 7-27. [CrossRef]

95. Ostrom, E. Understanding Institutional Diversity; Princeton University Press: Princeton, NJ, USA, 2005.

96. Grossman, P.Z. Utilizing Ostrom's institutional analysis and development framework toward an understanding of crisis-driven policy. Policy Sci. 2019, 52, 3-20. [CrossRef]

97. Iychettira, K.K.; Hakvoort, R.A.; Linares, P. Towards a comprehensive policy for electricity from renewable energy: An approach for policy design. Energy Policy 2017, 106, 169-182. [CrossRef]

98. Blomquist, W.; deLeon, P. The Design and Promise of the Institutional Analysis and Development Framework. Policy Stud. J. 2011, 39, 1-6. [CrossRef]

99. Brinkerhoff, J.M. Government-nonprofit partnership: A defining framework. Public Adm. Dev. 2002, 22, 19-30. [CrossRef]

100. Flinders, M. The Politics of Public-Private Partnerships. Br. J. Politics Int. Relat. 2005, 7, 215-239. [CrossRef]

101. Mahoney, J. Path Dependence in Historical Sociology. Theory Soc. 2000, 29, 507-548. [CrossRef]

102. Watts, M. Resource curse? governmentality, oil and power in the Niger Delta, Nigeria. Geopolitics 2004, 9, 50-80. [CrossRef]

103. Porter, D.; Watts, M. Righting the Resource Curse: Institutional Politics and State Capabilities in Edo State, Nigeria. J. Dev. Stud. 2017, 53, 249-263. [CrossRef] 
104. Ifeka, C. Oil, NGOs \& youths: Struggles for resource control in the Niger delta. Rev. Afr. Political Econ. 2001, 28, 99-105.

105. Dibua, J.I. Citizenship and Resource Control in Nigeria: The Case of Minority Communities in the Niger Delta. Afr. Spectr. 2005, 40, 5-28.

106. Rasmussen, M.B.; Lund, C. Reconfiguring Frontier Spaces: The territorialization of resource control. World Dev. 2018, 101, 388-399. [CrossRef]

107. Brown, M.M. Democratic Governance: Toward a Framework for Sustainable Peace. Glob. Gov. 2003, 9, 141-146. [CrossRef]

108. Omotola, J.S. From the OMPADEC to the NDDC: An Assessment of State Responses to Environmental Insecurity in the Niger Delta, Nigeria. Afr. Today 2007, 54, 73-89. [CrossRef]

109. Idemudia, U.; Ite, U.E. Demystifying the Niger Delta conflict: Towards an integrated explanation. Rev. Afr. Political Econ. 2006, 33, 391-406. [CrossRef]

110. Akpabio, E.M.; Akpan, N.S. Governance and Oil Politics in Nigeria's Niger Delta: The Question of Distributive Equity. J. Hum. Ecol. 2010, 30, 111-121. [CrossRef]

111. Rhodes, R.A.W. Understanding Governance: Policy Networks, Governance and Accountability; Open University Press: Buckingham, UK, 1997.

112. Galindo, M.-Á.; Méndez, M.T. Entrepreneurship, economic growth, and innovation: Are feedback effects at work? J. Bus. Res. 2014, 67, 825-829. [CrossRef]

113. Ashford, S.J. Feedback-Seeking in Individual Adaptation: A Resource Perspective. Acad. Manag. J. 1986, 29, 465-487.

114. Yin, R.K. Case Study Research Design and Methods, 5th ed.; Sage: Thousand Oaks, CA, USA, 2014; p. 282.

115. Hammarberg, K.; Kirkman, M.; de Lacey, S. Qualitative research methods: When to use them and how to judge them. Hum. Reprod. 2016, 31, 498-501. [CrossRef] [PubMed]

116. Blaikie, N. Designing Social Research, 2nd ed.; Polity: Cambridge, UK, 2010.

117. Mason, J. Qualitative Researching, 2nd ed.; Sage: London, UK, 2002.

118. Eisenhardt, K.M.; Graebner, M.E. Theory Building from Cases: Opportunities and Challenges. Acad. Manag. J. 2007, 50, 25-32. [CrossRef]

119. Chiesa, M.; Hobbs, S. Making sense of social research: How useful is the Hawthorne Effect? Eur. J. Soc. Psychol. 2008, 38, 67-74. [CrossRef]

120. Obi, C. Nigeria's Niger Delta: Understanding the Complex Drivers of Violent Oil-related Conflict. Afr. Dev. 2009, 34, 103-128. [CrossRef]

121. Davidheiser, M.; Nyiayaana, K. Demobilization or Remobilization? The Amnesty Program and the Search for Peace in the Niger Delta. Afr. Secur. 2011, 4, 44-64. [CrossRef]

122. Yun, J.J.; Liu, Z. Micro and Macro-Dynamics of Open Innovation with a Quadruple-Helix Model. Sustainability 2019, 11, 3301. [CrossRef]

123. Montagnino, F.M. Joseph Beuys' Rediscovery of Man-Nature Relationship: A Pioneering Experience of Open Social Innovation. J. Open Innov. 2018, 4, 50. [CrossRef]

124. Yun, J.J.; Won, D.; Park, K. Entrepreneurial cyclical dynamics of open innovation. J. Evol. Econ. 2018, 28, 1151-1174. [CrossRef]

125. Yun, J.J.; Park, K.B.; Hahm, S.D.; Kim, D. Basic Income with High Open Innovation Dynamics: The Way to the Entrepreneurial State. J. Open Innov. 2019, 5, 41. [CrossRef]

(C) 2019 by the authors. Licensee MDPI, Basel, Switzerland. This article is an open access article distributed under the terms and conditions of the Creative Commons Attribution (CC BY) license (http://creativecommons.org/licenses/by/4.0/). 